\title{
Pay for Environmental Performance: The Effect of Incentive Provision on Carbon Emissions
}

\section{Citation}

Eccles, Robert G., loannis loannou, Shelley Xin Li, and George Serafeim. "Pay for Environmental Performance: The Effect of Incentive Provision on Carbon Emissions." Harvard Business School Working Paper, No. 13-043, November 2012.

\section{Permanent link}

http://nrs.harvard.edu/urn-3:HUL.InstRepos:10018989

\section{Terms of Use}

This article was downloaded from Harvard University's DASH repository, and is made available under the terms and conditions applicable to Open Access Policy Articles, as set forth at http:// nrs.harvard.edu/urn-3:HUL.InstRepos:dash.current.terms-of-use\#OAP

\section{Share Your Story}

The Harvard community has made this article openly available.

Please share how this access benefits you. Submit a story.

Accessibility 
H A R VAR D

Pay for Environmental Performance: The Effect of Incentive Provision on Carbon Emissions

Robert G. Eccles

Ioannis Ioannou

Shelley Xin Li

George Serafeim

\section{Working Paper}

13-043

November 19, 2012 


\title{
Pay for Environmental Performance:
}

\section{The Effect of Incentive Provision on Carbon Emissions}

\author{
Robert G. Eccles, Ioannis Ioannou, Shelley Xin Li, and George Serafeim*
}

\begin{abstract}
Corporations are increasingly under pressure to improve their environmental performance and to account for potential risks and opportunities associated with climate change. In this paper, we examine the effectiveness of monetary and nonmonetary incentives provided by companies to their employees in order to reduce carbon emissions. Specifically, we find evidence that the use of monetary incentives is associated with higher carbon emissions. This result holds both in cross-sectional and time-series analysis. Moreover, we find that the use of nonmonetary incentives is associated with lower carbon emissions. Consistent with monetary incentives crowding out motivation for pro-social behavior, we find that the effect of monetary incentives on carbon emissions is mitigated when these incentives are provided to employees with formally assigned responsibility for environmental performance. Furthermore, by employing a two-stage multinomial logistic model, we provide insights into factors affecting companies' decisions on incentive provision, as well as showing that the impact of monetary incentives on carbon emissions remains significant even when we control for potential selection bias in our sample.
\end{abstract}

\footnotetext{
${ }^{*}$ Robert G. Eccles is a Professor of Management Practice at Harvard Business School. Ioannis Ioannou is an Assistant Professor of Strategy and Entrepreneurship at London Business School. Shelley Xin Li is a doctoral candidate at Harvard Business School. George Serafeim is an Assistant Professor of Business Administration at Harvard Business School. We are grateful to the Carbon Disclosure Project and in particular to Maia Kutner for giving access to the investor survey data. We thank Andrew Knauer for excellent research assistance. All errors are solely our own responsibility. Contact author: George Serafeim gserafeim@hbs.edu.
} 


\section{Introduction}

Climate change is currently a topic of great interest to corporations, investors, policy makers, and academics. The Stern Review, commissioned by the British Government, estimates the overall costs and risks of climate change to be equivalent to losing at least 5\% of global GDP each year (i.e., over \$3 trillion for 2010). Because of the role of greenhouse gases like carbon emissions in causing global warming and the massive consequences that climate change may have on the planet, a plethora of initiatives seeking to reduce the carbon emissions of both public and private organizations have emerged around the globe. Accordingly, many corporations are providing incentives to their employees geared towards reducing carbon emissions resulting from the firm's operations. Typically, the incentives provided to employees fall within two broad categories: they can be either monetary (e.g., cash bonuses) or nonmonetary (e.g., public recognition usually in the form of awards). In this paper, we investigate how effective such incentives are in terms of reducing carbon emissions for the firms that provide them.

Although policy makers have previously attempted to establish what came to be termed as a “carbon market," currently no global price has emerged for carbon emissions and, as a result, organizations with high emissions are not legally required to internalize the negative externalities that they impose on the environment, other organizations, and the society at large. Yet a number of organizations have voluntarily and unilaterally adopted corporate policies that require reduction of carbon emissions being generated by their operations. Such attempts at reducing carbon emissions can be characterized as pro-social behaviors (Benabou and Tirole, 2006) if the underlying reasoning for reducing emissions is not maximizing private gains but contributing to the public good.

However, many argue that companies voluntarily reduce carbon emissions because doing so is consistent with profit maximization. Greater energy efficiency saves money and carbon emissions at the same time. Furthermore, mounting social awareness with regards to the detrimental effects of climate change and the real possibility of regulatory and legislative actions provide other reasons for companies to voluntarily limit their carbon emissions. Doing so can lead to a positive reputation as a "good corporate citizen," thereby attracting employees and customers who are concerned about climate change and 
preserving the company’s socially-determined "license to operate." It can also lead to getting the benefit of the doubt from regulators regarding environmental issues already covered by regulation. Long-term investors who believe that future regulations are likely and/or who are "universal owners” and concerned about the effects of climate change on their overall portfolio will favor companies that are proactively responding to the relationship between carbon emissions and climate change. Finally, companies which make the investment today to reduce their carbon emissions will be in a strong position should regulation mandate reduced emissions or establish a price on them. They will conceivably have had the opportunity to phase in the investments required to do so, will be more knowledgeable about what is required to reduce emissions and, as a result, will be able to more quickly respond to new regulations and at a lower cost. All of these benefits to voluntarily reducing carbon emissions, even if they entail some short-term cost disadvantages due to the required investment, can create a competitive advantage in the long term. When the company makes a compelling economic argument for reducing carbon emissions it is less likely to be seen by employees as a pro-social activity but rather as a strategically implemented policy by the firm in order to remain competitive in product, labor, and capital markets.

Why employees exert efforts to reduce carbon emissions can have significant implications for the optimal design of incentive contracts. On the one hand, if employees are intrinsically motivated to reduce carbon emissions because they believe this will contribute to the public good then providing monetary incentives to reduce carbon emissions might actually crowd-out intrinsic motivation and lead to higher emissions. On the other hand, if employees exert efforts to reduce carbon emission because they believe this is economically the best course of action to ensure maximizing long-term profitability then monetary incentives will be effective at motivating employees. Here, we provide the first set of evidence towards answering this question. In particular, using data for a cross-section of firms across the globe, we find that firms that provide monetary incentives have higher carbon emissions compared to firms that give no incentives on environmental performance. Furthermore, we find that firms that provide nonmonetary incentives have lower carbon emissions compared to firms that give no incentives. We find these results after controlling for other determinants of carbon emission levels, such as the scale of the firm's 
operations, the adoption of corporate policies to reduce carbon emissions, the existence of commercial opportunities and risks from climate change, and the quality of sustainability governance. Moreover, we control for industry, country, and year fixed effects or for industry and country time-varying effects. In further analysis, we find similar results when we include firm fixed effects and estimate the coefficients using only within firm variation, as well as when we track the time-series evolution of carbon emissions for a matched sample of firms.

We further parse this question by varying the degree to which efforts to reduce carbon emissions is considered as pro-social behavior by employees. We posit that employees whose job descriptions explicitly include the responsibility for environmental performance and emissions reduction will be less likely to consider such goals as pro-social behavior since they are being rewarded for the instrumental reasons for doing so. Consistent with this argument, we empirically find that the negative effect of monetary incentives on reducing carbon emissions is completely mitigated when these incentives are provided to employees with direct responsibility for environmental performance. This is because their job responsibilities are based on an economic rationale for reduction in carbon emissions.

Finally, as a robustness test, we implement a two-stage multinomial logistic model, explicitly accounting in the first stage for a number of factors that could drive the probability of a focal firm choosing to adopt a monetary, a nonmonetary, both-monetary-and-non-monetary, or a no-incentive scheme linked to environmental goals. The results of this analysis are consistent with our main findings regarding the impact of monetary incentives. We also directionally find consistent but statistically insignificant results for the impact of non-monetary incentives on carbon emissions.

This study extends and complements a literature that investigates, documents, and explains the relative effectiveness of monetary vs. non-monetary incentives for improving task performance, especially when efforts are likely to be seen as pro-social behavior. First, by providing empirical evidence on such a critical issue as carbon emissions, we contribute to the debate in the literature on whether monetary incentives are effective in motivating particular and desired individual behaviors. On the one hand, there has been a large experimental literature documenting the negative effects of monetary 
incentives broadly known as the "crowding-out" effect. That is, monetary incentives can crowd out intrinsic motivation or reputational motivation for agents engaging in a given task and therefore result in the worsening of task performance. On the other hand, Prendergast (1999) notes that there is little conclusive empirical evidence documenting that monetary incentives could crowd-out motivation and lead to worse performance in workplace settings. Similarly, Gibbons (1998) suggests that management practices based on economic models may dampen non-economic realities such as motivation and social relations, and that empirical data would be useful in deepening our understanding of this issue. Whether and under what conditions do the negative effects of monetary incentives emerge in a real work place setting remain open questions. Our analysis provides empirical evidence that for tasks involving prosocial elements, monetary incentives are not effective and actually detrimental unless they are provided to people for whom such tasks constitute part of their formal job responsibility; otherwise, non-monetary incentives are likely to be more effective.

In addition, we contribute to the accounting literature that deals with how the task type and the type of incentive scheme affect the efficacy of monetary incentives and may influence the design of management accounting and control systems. In reviewing numerous laboratory-based studies in this literature, Bonner et al. (2000) find that monetary incentives improve performance in only about half of the experiments and argue that, as tasks become more cognitively complex, monetary incentives become less effective. Complementing this line of work, our study posits that an additional task characteristic, its pro-social nature, significantly impacts the effectiveness of different types of incentives and should also be considered in the design of accounting and control systems.

The remaining of the paper proceeds as follows. Section 2 discusses the motivation for this study and presents the literature review. Section 3 presents the sample and summary statistics. Section 4 discusses the results from the analyses. Finally, section 5 concludes.

\section{Motivation and Literature Review}

Carbon emissions can be thought of as the classic case of an externality. Organizations that emit large amounts of carbon increase the probability of future adverse environmental events that may negatively 
affect numerous other organizations, investors, and society as a whole. However, they do not internalize all the costs associated with carbon emissions since organizations with high carbon emissions might not be themselves adversely and directly affected by climate change (for example, due to their geographic location and due to the absence of a global carbon tax). Due to the firm not directly bearing the costs of its negative externalities and the lack of Pigovian taxation ${ }^{1}$, organizations emit more carbon than it is socially optimal. Consequently, employees of organizations that perceive their company as voluntarily engaging in activities to limit the negative externalities their company imposes on society without a direct or indirect economic benefit may be regarded as exhibiting pro-social behavior.

However, the broader issue of climate change - typically linked to carbon emissions - has become an increasingly important economic issue for companies due to several reasons. First, current and future expected regulations around the world would aim to limit the carbon footprint of corporations by either imposing a direct Pigovian tax on carbon emissions or by instituting cap-and-trade programs. In the former case, a firm pays a certain price for every ton of carbon emissions it generates during the course of its operations. In the latter case, corporations are allowed to emit carbon up to a certain amount, and if they exceed that amount then they need to buy carbon emission allowances in the market place. Both mechanisms increase operating costs in proportion to the amount of carbon emissions.

Another reason why carbon emission has become an important economic issue is because of the rapidly shifting social expectations regarding the environmental performance of corporations. Good environmental performance, including but not limited to a smaller carbon footprint, may be rewarded in the product, labor, and capital markets. Since customers, employees, and investors increasingly demand from companies to take measures to address climate change and limit their carbon emissions, firms with better environmental performance have more loyal and satisfied customers, who want to buy "greener"

\footnotetext{
${ }^{1}$ In the presence of negative externalities, the social cost of a market activity is not covered by the private cost of the activity, which could lead to an inefficient market and over-consumption of the product or resource. A Pigovian tax equal to the negative externality is thought to correct the market outcome back to efficiency.
} 
products” (Bhattacharya and Sen 2004), more engaged and satisfied employees, who want to work for a “greener” employer (Turban and Greening 1996), and face lower capital constraints since investors are building future carbon prices into their valuation decisions (Cheng, Ioannou, and Serafeim 2011). However, currently these market forces are pushing companies to only partially internalize the negative externalities of carbon emissions since the consequences of climate change are not yet equally understood by all stakeholders. In fact, such market imperfections are the reason why "carbon markets” have not yet been established.

Moreover, the partial internalization of the negative externality generates ambiguity at the level of the employees with regards to how tasks aimed at reducing carbon emissions will be perceived. On the one hand, if reducing carbon emissions is integrated as part of business strategy, then employees are more likely to perceive the associated tasks and efforts as part of their "regular” job responsibilities to support the economic interests of the firm. If, on the other hand, reducing carbon emissions is perceived as "doing good" for others (i.e., voluntarily dealing with the externality) at a short-term cost to the company and its investors, then employees will be more likely to perceive the tasks focused on carbon emissions as an expression of pro-social behavior, taking place in addition to their "regular" job responsibilities. Thus, regardless of the underlying motives at the company level for introducing an incentive scheme for reducing carbon emissions, the critical issue is understanding employees' motivation for reducing carbon emissions.

The academic literature includes many studies that have explored the effectiveness of monetary vs. nonmonetary incentives, in fields as diverse as economics, psychology, managerial accounting, education, and more. Within economics, agency theory studies the effect of monetary incentives on individual performance, arguing that monetary incentives are employed in order to align the principal's objectives with those of the agent's. Thus, the optimal contract is essentially a trade-off between risk sharing between the employee and the firm and incentive provisions, provided that the strength of the monetary incentives should be decreasing in proportion to the noise of the performance measures upon which the contract is based (Holmstrom 1979, Banker and Datar 1989). Empirical research on the effect 
of such monetary incentive contracts (i.e., pay-for-performance contracts) finds that individuals respond to monetary incentives either by working harder or by self-selecting into those pay-for-performance jobs that are the best match for their own ability level (Lazear, 2000). In psychology, the behavioral school also argues that monetary incentives have a positive effect on motivation by providing positive reinforcement, which in turn increases the frequency of the rewarded behaviors and results in enhanced performance (Skinner 1953).

However, monetary incentives may also induce distorted behaviors either through the individual’s misallocation of efforts into task dimensions that are easier to quantify and generate performance pay (Milgrom and Holmstrom 1991), or through the crowding-out of intrinsic motivation. More specifically, cognitive evaluation theory (CET) argues that people perform a given task driven by intrinsic motivation (e.g., playing a game could be fun in itself even without getting paid or getting praise), asserting that such an intrinsic motivation originates from the psychological need for autonomy and competence. Accordingly, the effects of an incentive scheme or a reward depend on how it affects the perceived selfdetermination and the perceived competence of the individual. Therefore, rewards or incentives may be interpreted by individuals primarily as being external controllers of their behavior or as being indicators of their competence. In the former case, the theory argues, rewards or incentives are predicted to thwart the need for autonomy and, therefore, to undermine intrinsic motivation. In the latter case however, when rewards are positively informational, they satisfy the individual's need for recognition of her competence and thus result in enhanced intrinsic motivation (Deci et al. 1999). Employees may take actions to reduce carbon emissions because they choose to do something that makes them feel good, in which case a bonus plan might take that sense of autonomy away by making people feel that they are now paid or required to do so. Alternatively, employees may take carbon emissions reduction actions precisely because they consider such actions as their formal job functions they are paid to perform, in which case a bonus might be a quite effective tool to enhance job performance. Thus the question is whether reducing carbon emissions is perceived by the employee as intrinsically-motivation driven, either due to demonstrating the 
exercise of autonomy or individual competence, or is based on external controls exercised on the individual's behavior.

The nature of the incentivized behavior - i.e., whether economically instrumental or pro-social can be a major determinant of the relative effectiveness of monetary vs. nonmonetary incentives. Relatedly, Benabou and Tirole (2006) develop a theory of pro-social behavior where the individual's behavior reflects an endogenous and unobservable mix of three motivations: intrinsic, extrinsic, and reputational motivation. Intrinsic motivation is the innate satisfaction accruing to the individual regardless of perceptions by others. Reputational motivation is the satisfaction accruing to the individual from positive perceptions others have of him or her. In our analysis, monetary incentives would fall under the category of extrinsic motivation, while nonmonetary incentives would fall under the category of intrinsic or reputational motivation. Furthermore, they find that the presence of extrinsic incentives diminishes the intrinsic value associated with performing good deeds, and therefore creating doubt regarding the extent to which such deeds were performed because of their benefit to the social good or because of the monetary incentives themselves. Furthermore, publicity and disclosure (e.g., public recognition) further strengthen the signaling motive in their model of pro-social behavior.

A large number of experimental as well as archival studies found empirical results that are consistent with these theoretical predictions. For example, Gneezy and Rustichini (2000a) conducted an experiment with Israeli day care providers, finding that when they instituted a fine for parents picking their children up late, late pickups in fat increased. Essentially, the fine was seen as a fee, an instrumental economic incentive, which parents could decide to pay and assuage any moral resistance to noncompliance. Frey and Oberholzer-Gee (1997) found that monetary incentives decreased the acceptance rate among citizens of a local community about whether a nuclear waste repository should have been located in their town. Kunreuther et al. (1990) found similar results for the siting of a nuclear repository in Nevada, where raising tax rebates failed to increase support for the project since they signaled the opposite of pro-social behavior. Gneezy and Rustichini (2000b) showed that for a group of pupils collecting donations for charity from households, only those groups that received substantial monetary 
rewards did as well as the groups that worked for free. All other groups that received moderate monetary rewards underperformed.

These studies that have explored the effectiveness of monetary vs. nonmonetary incentives have been conducted at the level of the individual by examining the effect of incentives on individual performance. The overall empirical and experimental evidence seem to point to mixed effects of monetary (nonmonetary) incentives depending on the nature of the tasks involved. The general lessons that can be drawn from this body of research are that monetary (nonmonetary) incentives tend to be less (more) effective when tasks are perceived as pro-social behavior (economically instrumental) motives.

We conduct our analysis on firm-level by examining the effectiveness of monetary vs. nonmonetary incentives on carbon emissions. On an aggregate level, we have no a priori predictions on the effectiveness of monetary incentives vs. nonmonetary incentives since we have no a priori knowledge on whether employees within the sample firms perceive reducing carbon emissions as pro-social behavior or not. However, we hypothesize that monetary incentives are less effective in reducing carbon emissions when firms place such monetary incentives on employees who perceive reducing carbon emissions as pro-social.

\section{Sample and Summary Statistics}

We obtain information on firms' incentive structures regarding climate change management through the investor survey of the Carbon Disclosure Project (CDP). The investor CDP survey requests information on the risks and opportunities of climate change from the world's largest companies (by market capitalization) on behalf of institutional investor signatories (in 2011, there were a total of 551 institutional investor signatories with a combined $\$ 71$ trillion in assets under management). The major goals of this survey are to provide investors with tools to assess the firms' climate risk, as well as to help firms develop abilities to provide comparable and relevant climate data to their shareholders. In the 2010 questionnaire, respondents included $84 \%$ of the European 300, $82 \%$ of the Global 500, $70 \%$ of the S\&P 
500, and 74\% of the South African 100 companies. See Appendix I for a more complete list of sample compositions around the world.

Starting in 2007, the investor CDP survey asked questions about whether firms provide incentives to manage climate change goals (e.g., carbon emission reduction targets), as well as the types of incentives provided (whether monetary or nonmonetary). Over the years, the response rate to these particular questions of incentive provision has increased from $76 \%$ to over $99 \%$ among survey participants. See Appendix II for a sample of answers from survey respondents.

These annual investor CDP surveys, to the best of our knowledge, are the first to provide direct, large-scale, cross-sectional data on the types of incentives provided by firms for a specific environmental performance dimension that would have otherwise not been available through archival datasets. The survey questions are designed to solicit answers on the existence of a particular management practice (e.g., yes/no answers), as opposed to answers on cognitive or affective assessment. Therefore, these questions are easier for generating more objective answers and are less subject to certain biases in survey studies, such as the scaling effects. ${ }^{2}$

We merge the data from all the public responses in investor CDP surveys (2007 to 2010) with the Thomson Reuters' ASSET4 database to provide information on firms' carbon emissions data, sustainability governance structure, and the adoption of climate management policies. ${ }^{3}$ After merging the datasets, we have a final sample size of 1,683 firm-year observations (794 unique firms).

Table 1 shows the summary statistics and variable definitions for this sample. We use the natural logarithm of carbon emissions and the natural logarithm of carbon emissions scaled by sales as dependent variables measuring a firm's environmental performance. The independent variables of interest are a pair

\footnotetext{
${ }^{2}$ Scale design and anchor choice will influence respondents' ratings, making it difficult to make comparisons across respondents.

${ }^{3}$ ASSET4 was a privately held Swiss-based firm (acquired by Thomson Reuters in 2009). The firm collects data and scores firms on environmental and social dimensions since 2002. Research analysts of ASSET4 collect more than 900 evaluation points per firm, where all the primary data used must be objective and publically available.

Subsequently, these 900 evaluation points are used as inputs to a default equal-weighted framework to calculate 250 key performance indicators (KPIs) that they further organize into 18 categories within 3 pillars: a) environmental performance score, b) social performance score and c) corporate governance score. Every year, a firm receives a zscore for each of the pillars, benchmarking its performance with the rest of the firms in the database.
} 
of indicator variables indicating whether the focal firm provides monetary or nonmonetary incentives directly linked to environmental performance. $42.1 \%$ of the firm-years are associated with monetary incentives, while $18.5 \%$ of the firm-years are associated with nonmonetary incentives. The average size of the firms in our sample (as measured by sales, employees, or assets) is relatively large due to the inclusion criterion (largest firms by market capitalization) in the investor CDP survey. On average, the firms in the sample have $\$ 8.6$ billion in sales, 21 thousand employees, and \$16 billion in assets. Moreover, $60 \%, 70 \%$, and $72 \%$ of the firm-years have corporate policies to reduce carbon emissions, transportation emissions, and supply chain emissions, respectively. Also, $70 \%$ of the firm-years are associated with the presence of a board committee responsible for sustainability and 65\% identify commercial risks and opportunities from climate change. Finally, 47\% provide an audit opinion on their sustainability disclosures.

Table 2 presents the correlation matrix for the variables considered in our analysis. Monetary incentives are positively correlated with carbon emissions scaled by sales, while nonmonetary incentives are negatively correlated with carbon emissions scaled by sales. The majority of the control variables (those not related to size) are positively correlated with carbon emissions, raising the possibility that these variables and the use of monetary incentives may be driven by the same underlying economic and technological forces. We use these variables to capture these potentially unobservable factors when estimating the effect of monetary and nonmonetary incentives on firms' environmental performance.

\section{Results}

\section{Base-line Analysis}

We first estimate the association between the adoption of incentives and carbon emissions by employing ordinary least squares (OLS) models that control for year, industry, and country fixed effects. The model employed in Table 3 column (1) is:

(1) Carbon emissions $_{i, t}=\alpha_{0}+\alpha_{1}$ Sales $_{i, t}+\beta_{1}$ Monetary $_{i, t}+\beta_{2}$ Nonmonetary $_{i, t}+$ Country Fixed Effects + Industry Fixed Effects + Year Fixed Effects 
The dependent variable is the natural logarithm of carbon emissions. Furthermore, we include a control for the scale of operations since the level of emissions is closely linked to the size of a firm's operations; we use the natural logarithm of sales to proxy for size. The independent variables of interest are two indicator variables that characterize whether a firm provides monetary or nonmonetary incentives to its employees. Table 3 column (1) shows the estimated coefficients and their statistical significance.

The model in column (1) explains $83.3 \%$ of the variation in the natural logarithm of carbon emissions. The coefficient on Monetary is positive and significant $(0.215, \mathrm{t}=3.08)$. In contrast, the coefficient on Nonmonetary is negative and marginally significant $(-0.141, \mathrm{t}=-1.76)$.

A potential explanation for the documented association between monetary incentives and the level of carbon emissions is that both are correlated with an unobserved third factor. For example, firms that make a clear commitment towards reducing their carbon footprint based on a solid business case will be more likely to provide monetary incentives but may very well have higher carbon emissions. The model in Table 3 column (2) addresses this alternative explanation by including more control variables that are likely to contribute to carbon emissions as well as affect the incentive policies.

(2) Carbon emissions $_{i, t}=\alpha_{0}+\alpha_{1}$ Sales $_{i, t}+\beta_{1}$ Monetary $_{i, t}+\beta_{2}$ Nonmonetary $_{i, t}+\gamma_{1}$ Corporate Policies $_{i, t}+\gamma_{2}$ Business Case for Climate Change Action $_{i, t}+\gamma_{3}$ Sustainability Governance $_{i, t}+$ Country Fixed Effects + Industry Fixed Effects + Year Fixed Effects

We include controls for the adoption of corporate policies to reduce carbon emissions, transportation and supply chain emissions, because corporate policies on reducing carbon emissions would have a direct effect on a firm's carbon emission level and also correlates with a firm's decision of providing incentives to reduce carbon emissions. Moreover, we include a control variable for firms that discuss in their annual or sustainability report the commercial opportunities and risks caused by climate change since such firms have a business case for climate change actions and are thus more likely to be affected by forces in the operating environment that both impact their carbon emissions and their incentive provisions on carbon emissions. Also, to capture the firm’s sustainability governance structure, we include controls for the commitment of the company towards sustainability, the presence of a board 
committee for sustainability, and a control for whether the firm undertakes an audit of its sustainability report.

Table 3 column (2) shows that the coefficients on Monetary and Nonmonetary remain positive and negative, respectively. Both are significant but the magnitude of the coefficient for monetary incentives somewhat decreases suggesting that this alternative explanation partly drives the association between Monetary and Emissions. All else equal, firms that provide monetary incentives have 17.8 percent higher emissions and firms that provide nonmonetary incentives have 14.6 percent lower emissions compared to firms that provide no carbon emission incentives at all.

Another potential explanation for the association between incentives and emissions is that we have imperfectly controlled for the scale of the firm's operations. To address this concern we include additional controls including the natural logarithm of the company's total assets and number of employees.

(3) Carbon emissions $_{i, t}=\alpha_{0}+\alpha_{1}$ Sales $_{i, t}+\alpha_{2}$ Employees $_{i, t}+\alpha_{3}$ Assets $_{i, t}+\beta_{1}$ Monetary $_{i, t}+\beta_{2}$ NonMonetary $_{i, t}+\gamma_{1}$ Corporate Policies $_{i, t}+\gamma_{2}$ Business Case for Climate Change Action $_{i, t}+\gamma_{3}$ Sustainability Governance $_{i, t}+$ Country Fixed Effects + Industry Fixed Effects + Year Fixed Effects

Column (3) shows that the results do not significantly change. All three scale variables load with a positive and significant coefficient, as expected. Moreover, when we alternatively use the natural logarithm of carbon emissions over sales as the dependent variable, our results effectively remain the same. Table 4, column (1) shows that the coefficient on Monetary is positive and significant $(0.169$, $\mathrm{t}=2.59)$ while the coefficient on Nonmonetary is negative and significant $(-0.154, \mathrm{t}=-1.99)$.

An additional concern is that we have inadequately controlled for industry membership by including 64 indicator variables; a more fine classification might be necessary. In column (2) of Table 4 we use an alternative industry classification that generates instead 104 indicator variables. Both coefficients of interest remain significant. The coefficient on Monetary is positive and significant $(0.131$, $\mathrm{t}=1.99)$ while the coefficient on Nonmonetary is negative and significant $(-0.136, \mathrm{t}=-1.97)$. 
A similar concern is that fixed effects are inadequately controlling for systematic shifts at the country or/and industry level in emission activity. To control for this effect, we introduce 130 timevarying country and 281 time-varying industry effects. A disadvantage of this approach is that introducing such a large number of indicator variables reduces the power of the statistical test. Column (3) shows that the coefficient on Monetary remains positive and significant. The coefficient on Nonmonetary remains negative, though it becomes insignificant.

Firm Fixed Effects Model and Matching Analysis

In Table 5 we introduce firm fixed effects in the specification to isolate any time-invariant firm-specific effects that might be creating a spurious correlation between the independent variables of interest and the dependent variable.

(4) Carbon emissions $_{i, t}=\alpha_{0}+\alpha_{1}$ Sales $_{i, t}+\beta_{1}$ Monetary $_{i, t}+\beta_{2}$ NonMonetary $_{i, t}+\gamma_{1}$ Corporate Policies $_{i, t}+\gamma_{2}$ Business Case for Climate Change Action $_{i, t}+\gamma_{3}$ Sustainability Governance $_{i, t}+$ Firm Fixed Effects + Country-year Fixed Effects + Industry-year Fixed Effects

The disadvantage of this approach is that the statistical power is significantly impaired because we do not have data for a long time-series available for each firm. We estimate this model using only 906 observations for 275 firms that individually have at least three observations. In column (1) of Table 5 the dependent variable is the natural logarithm of emissions while in column (2) it is the natural logarithm of emissions over sales. The results from these models are similar to the results of Tables 3 and 4 but, as expected, they are statistically weaker. Column (1) suggests that firms that provide monetary incentives have 7.1 percent higher emissions and firms that provide nonmonetary incentives have 9.9 percent lower emissions compared to firms that provide no incentives. Column (2) suggests that firms that provide monetary incentives have 11.3 percent higher emissions and firms that provide nonmonetary incentives have 12.8 percent lower emissions compared to firms that provide no incentives. These findings increase our confidence towards arguing that it is incentives that lead to the change in emissions rather than other factors. 
Table 6 reinforces the findings of Table 5 by showing the results of an analysis on a matched sample of firms. There are 103 units (firm-years) that switched from no incentive to monetary incentives only from year $t-1$ to year $t$. We label this group as the "treatment group." There are also 401 units providing no incentives from year $t-1$ to year $t$, which we label as the "control group." ${ }^{4}$ We first take all the units in the treatment group, and match each unit with two units in the control group that have: 1) exactly the same industry membership; 2) the closest value in carbon emissions scaled by sales in year $t$ $1^{5}$. Then we measure emissions over sales in years $t$ and $t+1$ to examine whether the treatment group that starts providing monetary incentives experiences an increase in emissions relative to the control group. Panel A of Table 6 shows the difference between treatment and control group for 185 pairs in years $t-1$ and $t$. The matching procedure appears to be working effectively since there is no statistical difference in emissions between the treatment and control group in year $t$-1. In contrast, emissions are actually higher for the treatment group in year $t$. The differences-in-differences estimate is 0.122 and significant at the 5 percent level. The results remain statistically significant when we consider emissions at year $t+1$ (Panel B).

Interaction Effects between Incentive Types and the Perceived Task Nature

As discussed in section 3, reduction of carbon emissions may also be conceptualized as pro-social behavior. Our findings are consistent with this idea by suggesting that monetary incentives might not only be ineffective but also detrimental in terms of task performance. In other words, monetary incentives may well crowd out intrinsic and reputational motivation for reducing carbon emissions. To provide more direct evidence of this mechanism, we generate interaction terms between the type of incentives provided

\footnotetext{
${ }^{4}$ Among the 103 (401) units in the treatment (treatment) group, 2 (6) units miss emission variables for year $\mathrm{t}-1 ; 4$ (11) units miss emission variables for year t; and 63 (204) units miss emission variables for year $t+1$.

${ }^{5}$ The reason that we choose from the control group two matching units for a treatment unit is because it offers the benefit of not relying on too little information without incorporating observations that are not sufficiently similar. And the fact that we have more control units than treatment units can afford us the opportunity of providing more than 1 matching unit. Some of the treatment units only find one control unit that meets the above criteria (hence we adjust the weight of such units to make every treatment unit carry the same weight).
} 
and the type of formal position that the incentivized employee occupies. In this respect, we argue that for employees whose job description specifically and directly includes environmental responsibilities, it would be less likely that monetary incentives will crowd out pro-social behavior (in contrast to senior executives, board members, geographic subsidiaries, or business unit managers). Exactly because of the nature of the position and the formally assigned responsibility, tasks or actions related to the environment, and environmental performance more broadly, would be considered as part of the typical contractual arrangement between the firm and the employee and, therefore, they would be perceived as legitimate for economically-instrumental reasons and not as based on pro-social behavior. In other words, the effect of monetary incentives on carbon emissions is likely to be mitigated when these incentives are provided to employees with assigned responsibility for environmental performance. The model used for this test is:

(5) Carbon emissions $_{i, t}=\alpha_{0}+\alpha_{1}$ Sales $_{i, t}+\beta_{1}$ Monetary $_{i, t}+\beta_{2}$ Nonmonetary $_{i, t}+\beta_{3}$ Environmental Position $_{i, t}+\beta_{4}$ Monetary $_{i, t} *$ Environmental Position $_{i, t}+\beta_{5}$ Nonmonetary $_{i, t} *$ Environmental $^{2}$ Position $_{i, t}+\gamma_{1}$ Corporate Policies $_{i, t}+\gamma_{2}$ Business Case for Climate Change Action $_{i, t}+\gamma_{3}$ Sustainability Governance $_{i, t}+$ Country Fixed Effects + Industry Fixed Effects + Year Fixed Effects

"Environmental Position" is an indicator variable that equals to one if the firm provides incentives to employees in positions directly responsible for environmental performance. In our sample, 27 percent of the total observations (i.e. across incentive types) and 55 percent of those providing monetary incentives offer these incentives to employees in roles and positions related to environmental performance. The results in Table 7 support our prediction. The coefficient on the interaction term between Monetary incentives and Environmental Position (an indicator variable that takes the value of one if the incentives are provided to employees with climate change relevant roles) is negative and significant when the dependent variable is the natural logarithm of carbon emissions $(-0.393, t=-2.78)$ or the natural logarithm of carbon emissions over sales $(-0.385, \mathrm{t}=-2.74)$.

Two-stage Multinomial Logistic Model 
Up to this point, we have discussed and empirically documented a statistically significant relationship between both monetary (negative association) and nonmonetary (positive association) incentives and reducing carbon emissions. Yet there is clearly an underlying selection issue that we still need to address: not all firms choose to provide employee incentives that are linked to environmental performance, and some may even provide both monetary and nonmonetary incentives to achieve their environmental goals (i.e., the adoption of an incentive scheme is not random as an experimental research design would dictate). In other words, we need to explicitly account for a first stage in which a focal firm decides whether or not to adopt some type of incentive scheme since doing so will allow us to address any potential selection bias in our findings. The existing literature on the issue of antecedents to pro-social behavior (e.g. Bansal \& Roth, 2000; Aguilera et al. 2007; Sharma \& Starik, 2002) argues that firms are driven towards engaging in socially responsible activities, such as the reduction of carbon emissions, by: a) potentially profitable economic opportunities, b) legitimacy seeking activities, typically resulting from institutional pressures and c) ethical, moral and/or normative concerns. Potentially profitable economic opportunities equates to economic instrumentality. Legitimacy-seeking activities equates to the reputational benefits of pro-social behaviour. Ethical, moral, and/or normative concerns equates to the intrinsic motivation aspect of pro-social behaviour. Accordingly, such motives may be classified in three distinct categories: economic (or instrumental) motives, reputational (or institutional) motives and ethical (or moral) motives (Aguilera et al. 2007; Bansal \& Roth, 2000; Bronn \& Vidaver-Cohen, 2009; Massa, 2012).

We argue that the adoption or not of an incentive scheme that aims to reduce carbon emissions will also be driven by these categories of motivation, economic, reputational, and ethical and therefore we propose a first stage multinomial logistic specification, modeling four distinct choices: a) no adoption, b) adoption of nonmonetary incentives only, c) adoption of monetary incentives only and d) adoption of both monetary and nonmonetary incentives.

First stage model: Probability (Incentive type $\left.e_{i, t}\right)=\alpha_{0}+\alpha_{1}$ Economic Motives $_{i t}+\alpha_{2}$ Reputational Motive $_{i t}$ $+\alpha_{3}$ Ethical Motives 
"Incentive Type" is a firm's actual choice from the aforementioned four choices. "Economic (reputational or ethical) Motives" represent variables that proxy for a firm’s tendency to adopt incentive plans to reduce carbon emissions due to economic (reputational or ethical) motives. For all categories, we include several controls in order to capture as comprehensively as possible the three categories of motives discussed above. In particular, firms that are larger (Sales) may be more likely to adopt an incentive scheme since due to their scale of operations they are better positioned to realize efficiency gains or cost reductions linked to reducing carbon emissions (i.e., more likely to be motivated by economic opportunities). The size of a firm is also likely to affect its reputational concerns due to its visibility in a business environment. In addition, firms that specifically explore Commercial Opportunities/Risks associated with sustainability as indicated by their public disclosures would be more likely to adopt an incentive scheme since they are structurally better positioned to understand and explore economic opportunities linked to carbon emissions. We also include "Bonus Plan" as a control variable for economic motives to adopt a certain incentive plan since whether a firm already has a performance-based bonus plan reflects a firm's belief in the effectiveness of monetary incentives as well as the difficulty of implementing an incentive plan.

Moreover, we proxy for a firm's reputational motives or institutional pressures for legitimacy that a firm may be facing (e.g., mimetic pressures) by calculating the percentage of other firms in any given country-year pair that have adopted monetary or nonmonetary incentives (\% monetary incentives for the country-year and \% nonmonetary incentives for the country-year).

We control for firms' ethical motives which will be perceived as pro-social by its employees in several ways. First, we argue that if a focal firm has been an early (pre-2002) signatory of the UN Global Compact (Join UN Global Compact by 2002) it did so based on ethical or reputational (rather than economic) motives and therefore we include an indicator variable as a predictor for incentive scheme adoption. Second, we argue that firms that have adopted a range of corporate policies that characterize a strong underlying sustainability culture (Eccles et. al, 2011) will also be more likely to adopt an incentive scheme linked to carbon emissions. Therefore, we control for a corporate policy to Reduce carbon 
emissions, to Reduce transportation emissions, and to Reduce supply chain emissions. Finally, firms that have a Sustainability Committee or perform a Sustainability Audit and are therefore relatively more transparent and credible with regards to their sustainability initiatives, and thus exhibit a stronger commitment towards this goal, will also be more likely to adopt incentive schemes linked to carbon emissions.

Panel A of Table 8 presents the results of the first stage multinomial logistic specification. In the first stage selection model, the probability of adopting a monetary (nonmonetary) incentive scheme is positively and significantly associated with the percentage of other firms in any given country-year pair that have adopted monetary (nonmonetary) incentives. The size of a firm, the existence of a sustainability committee, a bonus plan, and a corporate policy of reducing carbon emissions, as well as whether the firm is an early adopter of UN Global Compact, are all positively and significantly associated with the adoption of a monetary incentive scheme. That is to say, a larger firm that has established sustainability governance structure, carbon emissions reduction policy, and an existing bonus plan and that has joined UN Global Compact early is most likely to adopt a monetary incentive scheme. The adoption of both monetary and non-monetary incentive schemes is also positively and significantly related to the size of a firm and the existence of a bonus plan. In addition, a firm that has assessed the commercial opportunities and risks associated with carbon emissions is also more likely to adopt both incentive schemes.

Panel B of Table 8 presents the second stage results from an OLS regression where we control for the estimated (from the first stage) probability of adopting a specific type of incentive, in addition to country, industry and year fixed effects. Second stage model:

Carbon emissions $_{i, t}=\alpha_{0}+\alpha_{1}$ Sales $_{i, t}+\beta_{1}$ Monetary $_{i, t}+\beta_{2}$ Nonmonetary $_{i, t}+\beta_{3}$ Both Monetary and Nonmonetary $_{i, t}+\beta_{4}$ Predicted Probability of Adopting a Certain Incentive Type (from first stage) $+\gamma_{1}$

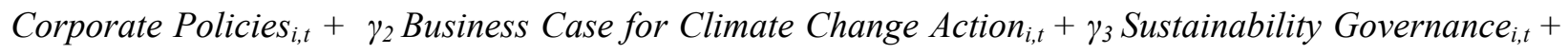
$\gamma_{4}$ Other Control Variables Used in the First Stage + Country Fixed Effects + Industry Fixed Effects + Year Fixed Effects 
In the second stage analysis, consistent with our previous results, we find that the exclusive adoption of monetary incentives significantly increases carbon emissions, whereas we find directionally consistent but insignificant results for nonmonetary incentives. Moreover, we find no effect on carbon emissions by the concurrent adoption of both monetary and nonmonetary incentives, suggesting a potential "cancel-out” of opposite effects from monetary and nonmonetary incentives. The coefficients on the control variables are similar to those in baseline regressions. Notice that the predicted probability of providing monetary incentives (calculated from the first stage) is positively and significantly associated with carbon emissions, indicating that there indeed exists a selection bias at least in the group that adopts monetary incentives (i.e. those who have a higher probability of adopting monetary incentives also have higher carbon emissions). Therefore, our additional tests to address those selection issues (through matching and two-stage selection model) are worthwhile.

Future research may seek to gain a deeper understanding of why this is the case by employing more fine grained data describing, for example, the relative share of monetary vs. nonmonetary incentives within an organization and also by exploring how different incentive schemes may be more or less effective if provided to different positions within an organizational hierarchy.

\section{Conclusion}

While past research has demonstrated that reducing carbon emissions and exhibiting good environmental performance is important for corporations, to the best of our knowledge no study has investigated the mechanisms of how these environmental goals may be achieved at a micro level within organizations. In this paper, we characterize and assess the effectiveness of different types of incentive schemes that corporations have adopted to incentivize behavior by their employees towards reducing carbon emissions. Our results show that contrary to the belief in the "seriousness" and effectiveness of monetary incentives on reducing carbon emissions, the adoption of monetary incentives is associated with higher carbon emissions. In contrast, the use of nonmonetary incentives is associated with lower carbon emissions. These results hold in cross-sectional analyses where we control for the size of the corporation, adoption of corporate policies to reduce emissions, the presence of commercial risks and opportunities due to climate 
change, and the quality of the organization's sustainability governance. Moreover, we find the same result when we introduce firm fixed effects and we use in the identification only within-firm variation or when we use a matched sample and we track carbon emissions over time. Importantly, we also find support for our results - directionally consistent but not significant for nonmonetary incentives - when we control for potential selection bias by explicitly accounting for the factors that may drive the decision of an organization of whether or not to adopt any incentive system at all aimed at reducing carbon emissions.

These results suggest that under some conditions (i.e., when employees perceive their action as pro-social behavior) the adoption of nonmonetary incentives might be more effective in reducing carbon emissions compared to monetary incentives. However, as in any non-laboratory analysis where the treatment effect is non-randomly applied, it is difficult to identify the causal effect. While it is conceivable that an unobservable factor exists that is positively correlated with monetary incentives, negatively correlated with nonmonetary incentives, and positively correlated with carbon emissions, we have not been able to identify such a factor. An alternative explanation is that reverse causality, at least with respect to monetary incentives, is generating our findings. In other words, firms that provide monetary incentives have higher carbon emissions. The analysis where we introduce firm fixed-effects partially addresses this concern and suggests that within the same firm, after the introduction of monetary incentives, carbon emissions increase relative to firms that do not provide monetary incentives. Moreover, the two-stage multinomial logistic model that we present yields results consistent with our initial analyses, at least with regard to monetary incentives, and suggests that any potential selection bias may not be as severe. A slightly different alternative explanation that introduces more complexity is that firms that have higher carbon emissions and that expect their carbon emissions to increase in the future years provide monetary incentives.

We recognize a number of other caveats related to our work. Our sample is comprised of large predominantly multinational organizations. It is possible that the effects documented here do not obtain for small firms that are competing only locally. Moreover, we have been able to examine only four years of data. It could well be that analyzing data over a longer time horizon may produce somewhat different 
results if there is a time lag between the introduction of incentive systems and their eventual effect. We believe that all of these issues are fruitful areas for future research.

Still, this study raises an important practical question. The practical question is what is the best way for a firm to explain the voluntary adoption of a carbon reduction program and its related incentives? The economically instrumental argument is most palatable to investors and begs for a matching incentive scheme in order to be perceived as "real” rather than "greenwashing." Ironically, though, the associated monetary incentives may actually be counterproductive except for these few employees whose jobs are directly focused on energy efficiency and the reduction of carbon emissions. The firm's explanation of its motives as normative in support of pro-social behavior, reinforced by nonmonetary incentive schemes for all other employees, may be more effective in reducing carbon emissions.

\section{References}

Aguilera, R.V., Rupp, D.E., Williams, C.A., \& Ganapathi, J. 2007. Putting the S back in corporate social responsibility: A multilevel theory of social change in organizations. Academy of Management Review, 32: 836-863.

Banker R. and S. Datar 1989. Sensitivity, Precision, and Linear Aggregation of Signals for Performance Evaluation. Journal of Accounting Research, 27 (1): 21-39.

Bansal, P. \& Roth, K. 2000. Why Companies Go Green: A Model of Ecological Responsiveness, Academy of Management Journal 43: 717-736.

Bénabou, R. and J. Tirole. 2006. Incentives and Prosocial Behavior. The American Economic Review 96 (5): 1652-1678.

Bonner, S. E., R. Hastie, G. B. Sprinkle, and S. M. Young 2000. A review of the effects of financial incentives on performance by laboratory tasks: Implications for management accounting. Journal of Management Accounting Research 12(1): 19-64.

Cheng, B., Ioannou, I., and Serafeim, G. 2011. Corporate Social Responsibility and Access to Finance. Harvard Business School Working Paper.

Deci, E., Koestner, R. and R. Ryan 1999. A Meta-Analytic Review of Experiments Examining the Effects of Extrinsic Rewards on Intrinsic Motivation. Psychological Bulletin, 125 (6): 627-668.

Frey, B. and F. Oberholzer-Gee 1997. The Cost of Price Incentives: An Empirical Analysis of Motivation Crowding-out. The American Economic Review, 87 (4): 746-755.

Gibbons, R. 1998. Incentives in Organizations. NBER Working Paper Series. 
Gneezy, U. and A. Rustichini 2000a. A Fine is a Price. Journal of Legal Studies, vol. XXIX.

Gneezy, U. and A. Rustichini 2000b. Pay Enough or Don’t Pay At All. The Quarterly Journal of Economics, 115 (3): 791-810.

Holmstrom, B. 1979. Moral Hazard and Observability. The Bell Journal of Economics, 10 (1): 74-91

Holmstrom, B. and P. Milgrom 1991. Multitask Principal-Agent Analyses: Incentive Contracts, Asset Ownership, and Job Design. Journal of Law, Economics and Organization, 7: 24-52.

Kunreuther, H., Easterling D., Desvousges, W. and P. Slovic 1990. Public Attitudes Toward Siting a High Level Nuclear Waste Depository in Nevada. Risk Analysis, 10: 469-484.

Lazear, E.P. 1999. Personnel economics. Past lessons and future directions. Journal of Labor Economics 17(2): 199-236.

Massa, L. 2012. Achieving superior sustainability performance: Instrumentality, legitimacy, ethics and slack resources. IESE Business School, Working Paper

Prendergast, C. 1999. The Provision of Incentives in Firms. Journal of Economic Literature, 37 (1): 7-63

Sharma S. \& Starik M., 2002 Research in corporate sustainability, Northampton, Massachusetts: Edward Elgar Publishing.

Skinner, B. F. 1953. Science and human behavior. New York: Macmillan.

Stern, N. 2007. Stern Review on the Economics of Climate Change. Cambridge University Press 
Table 1: Descriptive Statistics and Variable Definitions

\begin{tabular}{|c|c|c|c|c|}
\hline Variable & Variable Definition & Observations & Mean & Std. Dev. \\
\hline carbon emissions & $\begin{array}{l}\text { Natural logarithm of carbon emissions } \\
\text { (scope } 1 \text { and } 2 \text { as measured in tons) }\end{array}$ & 1,683 & 13.258 & 2.387 \\
\hline $\begin{array}{l}\text { carbon emissions scaled by } \\
\text { sales }\end{array}$ & $\begin{array}{l}\text { Natural logarithm of carbon emissions } \\
\text { (scope } 1 \text { and } 2 \text { as measured in tons) over sales }\end{array}$ & 1,683 & 4.196 & 2.040 \\
\hline Monetary & $\begin{array}{l}\text { An indicator variable that equals to } 1 \text { if the firm provides } \\
\text { monetary incentives in that year }\end{array}$ & 1,683 & 0.421 & 0.494 \\
\hline Nonmonetary & $\begin{array}{l}\text { An indicator variable that equals to } 1 \text { if the firm provides } \\
\text { non-monetary incentives in that year }\end{array}$ & 1,683 & 0.185 & 0.388 \\
\hline Sales & $\begin{array}{l}\text { Natural logarithm of sales } \\
\text { (measured in million USDs) }\end{array}$ & 1,683 & 9.062 & 1.449 \\
\hline Employees & Natural logarithm of number of employees & 1,602 & 9.945 & 1.525 \\
\hline Assets & $\begin{array}{l}\text { Natural logarithm of assets } \\
\text { (measured in million USDs) }\end{array}$ & 1,683 & 9.692 & 1.661 \\
\hline Reduce carbon emissions & $\begin{array}{l}\text { An indicator variable that equals to } 1 \text { if the firm has a policy } \\
\text { to reduce carbon emissions }\end{array}$ & 1,683 & 0.596 & 0.491 \\
\hline Sustainability committee & $\begin{array}{l}\text { An indicator variable that equals to } 1 \text { if the firm has a } \\
\text { sustainability committee on the board }\end{array}$ & 1,683 & 0.704 & 0.457 \\
\hline $\begin{array}{l}\text { Commercial } \\
\text { opportunities/risks }\end{array}$ & $\begin{array}{l}\text { An indicator variable that equals to } 1 \text { if the firm has assessed } \\
\text { commercial opportunities/risks related to climate change }\end{array}$ & 1,683 & 0.647 & 0.478 \\
\hline $\begin{array}{l}\text { Reduce transportation } \\
\text { emissions }\end{array}$ & $\begin{array}{l}\text { An indicator variable that equals to } 1 \text { if the firm has a policy } \\
\text { to reduce carbon emissions related to transportation }\end{array}$ & 1,683 & 0.694 & 0.461 \\
\hline Reduce supply chain emissions & $\begin{array}{l}\text { An indicator variable that equals to } 1 \text { if the firm has a policy } \\
\text { to reduce carbon emissions from its supply chain }\end{array}$ & 1,683 & 0.720 & 0.449 \\
\hline Sustainability audit & $\begin{array}{l}\text { An indicator variable that equals to } 1 \text { if the firm has its } \\
\text { sustainability performance measures externally audited }\end{array}$ & 1,683 & 0.473 & 0.499 \\
\hline Environmental positions & $\begin{array}{l}\text { An indicator variable that equals to } 1 \text { if the firm provides } \\
\text { incentives to employees in positions responsible for } \\
\text { environmental performance. }\end{array}$ & 1,659 & 0.269 & 0.443 \\
\hline
\end{tabular}


Table 2: Correlation Matrix

\begin{tabular}{|c|c|c|c|c|c|c|c|c|c|c|c|c|c|c|}
\hline & I & II & III & IV & V & VI & VIII & IX & $\mathrm{X}$ & XI & XII & XIII & XIV & $\mathrm{XV}$ \\
\hline carbon emissions & 1.000 & & & & & & & & & & & & & \\
\hline $\begin{array}{l}\text { carbon emissions scaled by } \\
\text { sales }\end{array}$ & 0.806 & 1.000 & & & & & & & & & & & & \\
\hline Monetary & 0.187 & 0.102 & 1.000 & & & & & & & & & & & \\
\hline Nonmonetary & 0.038 & -0.018 & 0.287 & 1.000 & & & & & & & & & & \\
\hline Sales & 0.529 & -0.076 & 0.168 & 0.089 & 1.000 & & & & & & & & & \\
\hline Employees & 0.432 & -0.072 & 0.150 & 0.084 & 0.831 & 1.000 & & & & & & & & \\
\hline Assets & 0.323 & -0.181 & 0.149 & 0.067 & 0.803 & 0.568 & 1.000 & & & & & & & \\
\hline Reduce carbon emissions & 0.374 & 0.291 & 0.175 & 0.108 & 0.213 & 0.158 & 0.079 & 1.000 & & & & & & \\
\hline Sustainability committee & 0.168 & 0.076 & 0.238 & 0.142 & 0.175 & 0.143 & 0.186 & 0.168 & 1.000 & & & & & \\
\hline Commercial opportunities/risks & 0.152 & 0.067 & 0.117 & 0.007 & 0.159 & 0.125 & 0.185 & 0.110 & 0.149 & 1.000 & & & & \\
\hline $\begin{array}{l}\text { Reduce transportation } \\
\text { emissions }\end{array}$ & -0.059 & -0.180 & 0.105 & 0.103 & 0.159 & 0.181 & 0.111 & 0.225 & 0.123 & 0.053 & 1.000 & & & \\
\hline Reduce supply chain emissions & 0.053 & -0.087 & 0.196 & 0.107 & 0.213 & 0.217 & 0.174 & 0.278 & 0.234 & 0.153 & 0.305 & 1.000 & & \\
\hline Sustainability audit & 0.169 & 0.071 & 0.174 & 0.081 & 0.184 & 0.135 & 0.205 & 0.184 & 0.201 & 0.137 & 0.098 & 0.215 & 1.000 & \\
\hline Environmental positions & 0.082 & -0.011 & 0.547 & 0.336 & 0.154 & 0.151 & 0.176 & 0.122 & 0.163 & 0.128 & 0.113 & 0.155 & 0.104 & 1.000 \\
\hline
\end{tabular}


Table 3: Incentives and Carbon Emissions

\begin{tabular}{|c|c|c|c|c|c|c|}
\hline & \multicolumn{6}{|c|}{ Carbon emissions } \\
\hline & \multicolumn{2}{|c|}{ (1) } & \multicolumn{2}{|c|}{ (2) } & \multicolumn{2}{|c|}{ (3) } \\
\hline & Coefficient & t-stat. & Coefficient & t-stat. & Coefficient & $t$-stat. \\
\hline \multicolumn{7}{|l|}{ Incentives } \\
\hline Monetary & 0.215 & $3.08^{\mathrm{a}}$ & 0.178 & $2.72^{\mathrm{a}}$ & 0.178 & $2.87^{\mathrm{a}}$ \\
\hline Nonmonetary & -0.141 & $-1.76^{\mathrm{c}}$ & -0.146 & $-1.88^{c}$ & -0.142 & $-1.93^{c}$ \\
\hline \multicolumn{7}{|l|}{ Scale } \\
\hline Sales & 1.004 & $31.14^{\mathrm{a}}$ & 0.964 & $26.23^{\mathrm{a}}$ & 0.242 & $2.29^{\mathrm{b}}$ \\
\hline Employees & & & & & 0.467 & 4.63a \\
\hline Assets & & & & & 0.369 & $4.90^{\mathrm{a}}$ \\
\hline \multicolumn{7}{|l|}{ Corporate Policies } \\
\hline Reduce carbon emissions & & & 0.345 & $3.68^{\mathrm{a}}$ & 0.291 & $3.01^{\mathrm{a}}$ \\
\hline Reduce transportation emissions & & & -0.171 & $-1.87^{\mathrm{C}}$ & -0.165 & $-1.76^{\mathrm{c}}$ \\
\hline Reduce supply chain emissions & & & -0.176 & $-2.07^{\mathrm{b}}$ & -0.190 & $-2.35^{\mathrm{b}}$ \\
\hline \multicolumn{7}{|c|}{ Business case for climate change action } \\
\hline Commercial opportunities/risks & & & 0.076 & 1.11 & 0.044 & 0.66 \\
\hline \multicolumn{7}{|l|}{ Sustainability Governance } \\
\hline Sustainability committee & & & 0.134 & 1.62 & 0.081 & 1.08 \\
\hline Sustainability audit & & & 0.267 & $3.48^{\mathrm{a}}$ & 0.236 & $3.17^{\mathrm{a}}$ \\
\hline Intercept & 5.839 & 11.61 & 5.813 & 12.07 & 4.010 & 7.46 \\
\hline Country fixed effects & Yes & & Yes & & Yes & \\
\hline Industry fixed effects & Yes & & Yes & & Yes & \\
\hline Year fixed effects & Yes & & Yes & & Yes & \\
\hline Adj R-squared & $83.3 \%$ & & $84.0 \%$ & & $85.7 \%$ & \\
\hline $\mathrm{N}$ & 1,683 & & 1,683 & & 1,602 & \\
\hline
\end{tabular}

(1): OLS regression using Sales as a proxy for scale; (2): OLS regression controlling for corporate policies, business case for climate change action, and sustainability governance; (3) OLS regression using number of employees (Employees) and Assets as additional proxies for scale. All OLS regressions control for country fixed effects, industry fixed effects and year fixed effects. The dependent variable is the natural logarithm of carbon emissions.

a. $\mathrm{p}<0.01 ;$ b. $\mathrm{p}<0.05 ;$ c. $\mathrm{p}<0.10$ 
Table 4: Incentives and Carbon Emissions - Robustness tests

\begin{tabular}{|c|c|c|c|c|c|c|}
\hline & \multicolumn{2}{|c|}{ Carbon emissions/ sales } & \multicolumn{2}{|c|}{ Carbon emissions } & \multicolumn{2}{|c|}{ Carbon emissions } \\
\hline & \multicolumn{2}{|c|}{ (1) } & \multicolumn{2}{|c|}{ (2) } & \multicolumn{2}{|c|}{ (3) } \\
\hline & Coefficient & t-stat. & Coefficient & t-stat. & Coefficient & $t$-stat. \\
\hline \multicolumn{7}{|l|}{ Incentives } \\
\hline Monetary & 0.169 & $2.59^{\mathrm{a}}$ & 0.131 & $1.99^{b}$ & 0.185 & $2.63^{\mathrm{a}}$ \\
\hline Nonmonetary & -0.154 & $-1.99^{b}$ & -0.136 & $-1.97^{b}$ & -0.107 & -1.21 \\
\hline \multicolumn{7}{|l|}{ Scale } \\
\hline Sales & & & 0.083 & 0.81 & 0.284 & $2.56^{\mathrm{b}}$ \\
\hline Employees & & & 0.563 & $7.07^{\mathrm{a}}$ & 0.442 & $4.19^{\mathrm{a}}$ \\
\hline Assets & & & 0.397 & $4.74^{\mathrm{a}}$ & 0.345 & $4.28^{\mathrm{a}}$ \\
\hline \multicolumn{7}{|l|}{ Corporate Policies } \\
\hline Reduce carbon emissions & 0.338 & $3.66^{\mathrm{a}}$ & 0.197 & $2.43^{\mathrm{b}}$ & 0.338 & $3.14^{\mathrm{a}}$ \\
\hline Reduce transportation emissions & -0.173 & $-1.88^{\mathrm{c}}$ & -0.148 & $-1.67^{\mathrm{c}}$ & -0.173 & $-1.65^{\mathrm{c}}$ \\
\hline Reduce supply chain emissions & -0.191 & $-2.36^{\mathrm{b}}$ & -0.158 & $-1.87^{\mathrm{c}}$ & -0.182 & $-2.00^{\mathrm{b}}$ \\
\hline \multicolumn{7}{|c|}{ Business case for climate change action } \\
\hline Commercial opportunities/risks & 0.070 & 1.03 & 0.040 & 0.60 & 0.062 & 0.83 \\
\hline \multicolumn{7}{|l|}{ Sustainability Governance } \\
\hline Sustainability committee & 0.122 & 1.51 & 0.075 & 0.97 & 0.102 & 1.21 \\
\hline Sustainability audit & 0.253 & $3.34^{\mathrm{a}}$ & 0.264 & $3.44^{\mathrm{a}}$ & 0.233 & $2.82^{\mathrm{a}}$ \\
\hline Intercept & 5.578 & 12.88 & 4.083 & 8.28 & 3.811 & 6.30 \\
\hline Country fixed effects & Yes & & Yes & & No & \\
\hline Industry fixed effects & Yes & & No & & No & \\
\hline Year fixed effects & Yes & & Yes & & No & \\
\hline Subsector fixed effects & No & & Yes & & No & \\
\hline Country-year fixed effects & No & & No & & Yes & \\
\hline Industry-year fixed effects & No & & No & & Yes & \\
\hline Adj R-squared & $78.1 \%$ & & $86.3 \%$ & & $84.6 \%$ & \\
\hline $\mathrm{N}$ & 1,683 & & 1,602 & & 1,602 & \\
\hline
\end{tabular}

(1): OLS regression using the natural logarithm of carbon emissions scaled by sales as the dependent variable; (2) OLS regression using the natural logarithm of carbon emissions as the dependent variable and controlling for subsector fixed effects by using a finer classification of industry; (3) OLS regression using the natural logarithm of carbon emissions as the dependent variable and controlling for country-year fixed effects and industry-year fixed effects.

a. $\mathrm{p}<0.01$; b. $\mathrm{p}<0.05 ;$ c. $\mathrm{p}<0.10$ 
Table 5: Incentives and carbon Emissions - Within Firm Estimates

\begin{tabular}{|c|c|c|c|c|}
\hline & Carbon & sions & Carbon er & ns/sales \\
\hline & Coefficient & t-stat. & Coefficient & t-stat. \\
\hline Incentives & & & & \\
\hline Monetary & 0.071 & 1.64 & 0.113 & $2.29^{\mathrm{a}}$ \\
\hline Nonmonetary & -0.099 & -1.39 & -0.128 & -1.57 \\
\hline Scale & & & & \\
\hline Sales & 0.117 & 0.83 & & \\
\hline Corporate Policies & & & & \\
\hline Reduce carbon emissions & 0.042 & 0.43 & 0.060 & 0.58 \\
\hline Reduce transportation emissions & -0.122 & -1.17 & -0.089 & -0.77 \\
\hline Reduce supply chain emissions & 0.079 & 1.10 & 0.096 & 1.30 \\
\hline Business case for climate change & & & & \\
\hline Commercial opportunities/risks & 0.091 & 0.76 & 0.149 & 1.18 \\
\hline Sustainability Governance & & & & \\
\hline Sustainability committee & 0.000 & 0.00 & -0.018 & -0.25 \\
\hline Sustainability audit & 0.187 & 1.47 & 0.193 & 1.33 \\
\hline Firm fixed effects & Yes & & Yes & \\
\hline Country-year fixed effects & Yes & & Yes & \\
\hline Industry-year fixed effects & Yes & & Yes & \\
\hline Adj R-squared & $97.8 \%$ & & $98.6 \%$ & \\
\hline $\mathrm{N}$ & 906 & & 906 & \\
\hline
\end{tabular}

(1): OLS regression using the natural logarithm of carbon emissions as the dependent variable and controlling for firm fixed effects; (2): OLS regression using the natural logarithm of carbon emissions scaled by sales as the dependent variable and controlling for firm fixed effects.

a. $\mathrm{p}<0.01 ;$ b. $\mathrm{p}<0.05 ;$ c. $\mathrm{p}<0.10$ 
Table 6: Incentives and carbon Emissions Scaled by Sales - Matched Sample

Panel A: Effect in year t

\begin{tabular}{||lcc||}
\hline & Diff=Treatment-Control & p-value \\
\hline $\mathrm{t}-1$ & 0.021 & 0.676 \\
$\mathrm{t}$ & 0.143 & 0.028 \\
Diffs-in-diffs & $\mathbf{0 . 1 2 2}$ & $\mathbf{0 . 0 4 6}^{\mathbf{b}}$ \\
\hline
\end{tabular}

Panel B: Effect in year $\mathrm{t}+1$

\begin{tabular}{||lcc||}
\hline & Diff=Treatment-Control & p-value \\
\hline $\mathrm{t}-1$ & -0.080 & 0.504 \\
$\mathrm{t}+1$ & 0.355 & 0.057 \\
Diffs-in-diffs & $\mathbf{0 . 4 3 5}$ & $\mathbf{0 . 0 4 9}^{\mathbf{b}}$ \\
\hline
\end{tabular}

Panel A shows the differences in the natural logarithm of carbon emissions scaled by sales in year $\mathrm{t}-1$ and year $\mathrm{t}$ between the treatment group and its matched sample of control units (matched by exact industry and the closest values of carbon emissions scaled by sales in year t-1).

Panel B shows the differences in the natural logarithm of carbon emissions scaled by sales in year $\mathrm{t}-1$ and year $\mathrm{t}+1$ between the treatment group and its matched sample of control units (matched by exact industry and the closest values of carbon emissions scaled by sales in year t-1).

a. $\mathrm{p}<0.01$; b. $\mathrm{p}<0.05$; c. $\mathrm{p}<0.10$ 
Table 7: Incentives and carbon Emissions - Employee type

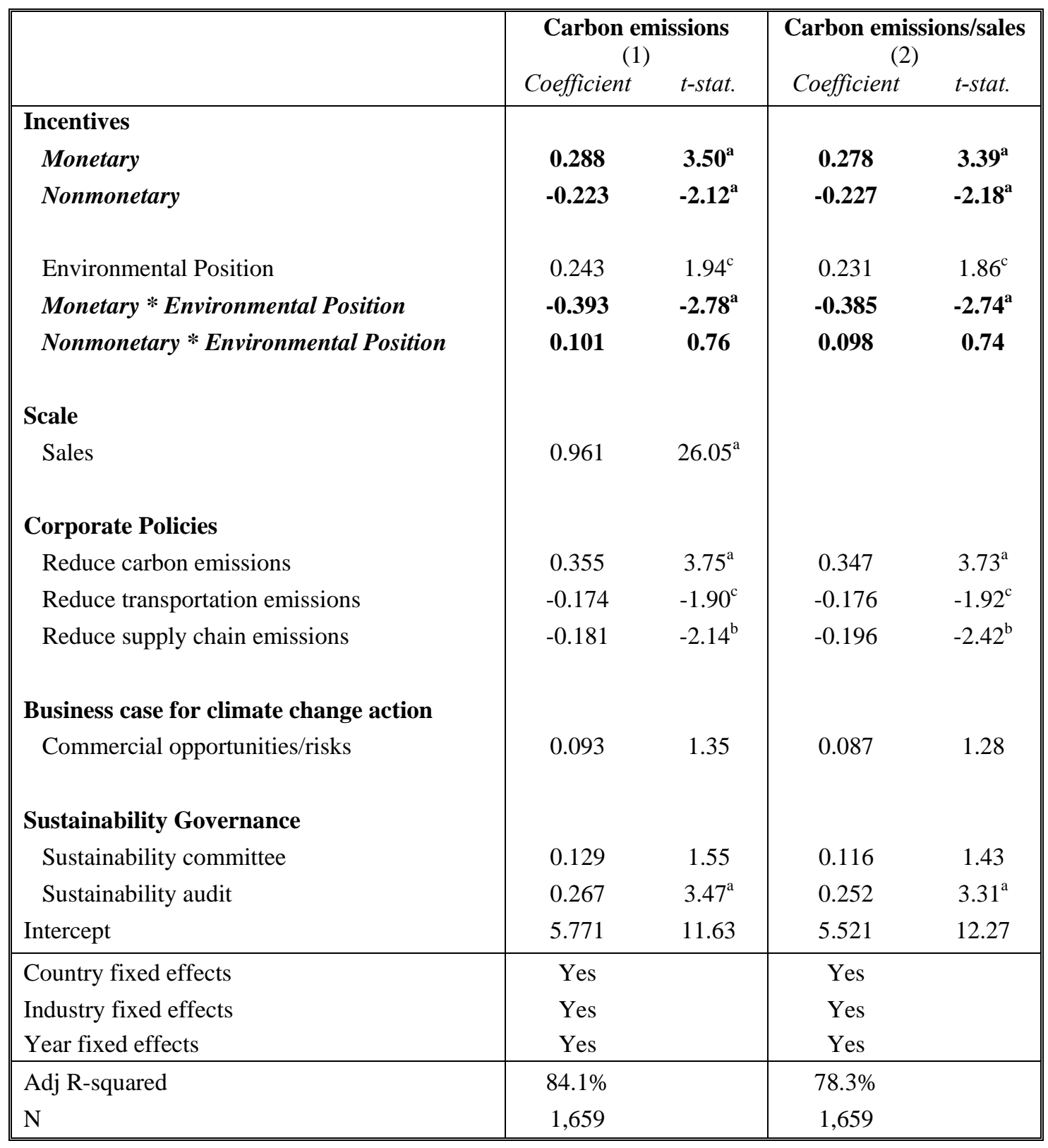

(1): OLS regression using the natural logarithm of carbon emissions as the dependent variable, with interaction terms between the type of incentives (Monetary or Nonmonetary) and Environmental Position; (2): OLS regression using the natural logarithm of carbon emissions scaled by sales as the dependent variable, with interaction terms between the type of incentives (Monetary or Nonmonetary) and Environmental Position.

a. $\mathrm{p}<0.01$; b. $\mathrm{p}<0.05 ;$ c. $\mathrm{p}<0.10$ 
Table 8: Panel A - First Step, Multinomial Logistic Regression

\begin{tabular}{|c|c|c|c|}
\hline Incentive Type & Firm Motives & Coefficient & $t$-stat. \\
\hline No Incentive & & (base outcome) & \\
\hline \multicolumn{4}{|l|}{ Only Non-monetary } \\
\hline Sales & Economic/Reputational & -0.014 & -0.13 \\
\hline Commercial Opportunities/Risks & Economic & 0.105 & 0.36 \\
\hline Bonus Plan & Economic & 0.280 & 0.93 \\
\hline$\%$ monetary incentives for the country-year & Reputational & 0.020 & 0.02 \\
\hline$\%$ non-monetary incentives for the country-year & Reputational & 9.788 & $10.91^{\mathrm{a}}$ \\
\hline Join UN Global Compact by 2002 & Reputational/Ethical & 0.523 & 0.70 \\
\hline Sustainability Committee & Reputational/Ethical & 0.286 & 0.86 \\
\hline Sustainability audit & Reputational/Ethical & 0.010 & 0.04 \\
\hline Reduce carbon emissions & All three & 0.472 & 1.56 \\
\hline Reduce transportation emissions & All three & 0.064 & 0.20 \\
\hline Reduce supply chain emissions & All three & -0.297 & -0.87 \\
\hline Intercept & & -5.465 & -5.03 \\
\hline \multicolumn{4}{|l|}{ Only Monetary } \\
\hline Sales & Economic/Reputational & 0.103 & $1.72^{\mathrm{c}}$ \\
\hline Commercial Opportunities/Risks & Economic & 0.173 & 1.05 \\
\hline Bonus Plan & Economic & 0.522 & $2.93^{\mathrm{a}}$ \\
\hline$\%$ monetary incentives for the country-year & Reputational & 5.552 & $12.36^{\mathrm{a}}$ \\
\hline$\%$ non-monetary incentives for the country-year & Reputational & -0.708 & -1.47 \\
\hline Join UN Global Compact by 2002 & Reputational/Ethical & 0.881 & $2.60^{\mathrm{a}}$ \\
\hline Sustainability Committee & Reputational/Ethical & 0.568 & $3.02^{\mathrm{a}}$ \\
\hline Sustainability audit & Reputational/Ethical & 0.194 & 1.19 \\
\hline Reduce carbon emissions & All three & 0.515 & $3.04^{\mathrm{a}}$ \\
\hline Reduce transportation emissions & All three & -0.160 & -0.90 \\
\hline Reduce supply chain emissions & All three & 0.091 & 0.45 \\
\hline Intercept & & -5.103 & -8.99 \\
\hline \multicolumn{4}{|l|}{ Both Monetary and Non-monetary } \\
\hline Sales & Economic/Reputational & 0.268 & $3.01^{\mathrm{a}}$ \\
\hline Commercial Opportunities/Risks & Economic & 0.594 & $2.50^{\mathrm{b}}$ \\
\hline Bonus Plan & Economic & 0.714 & $2.87^{\mathrm{a}}$ \\
\hline$\%$ monetary incentives for the country-year & Reputational & 5.646 & $7.54^{\mathrm{a}}$ \\
\hline$\%$ non-monetary incentives for the country-year & Reputational & 6.371 & $10.08^{\mathrm{a}}$ \\
\hline Join UN Global Compact by 2002 & Reputational/Ethical & -0.059 & -0.11 \\
\hline Sustainability Committee & Reputational/Ethical & 0.399 & 1.30 \\
\hline Sustainability audit & Reputational/Ethical & 0.157 & 0.72 \\
\hline Reduce carbon emissions & All three & 0.268 & 1.14 \\
\hline Reduce transportation emissions & All three & -0.006 & -0.02 \\
\hline Reduce supply chain emissions & All three & 0.389 & 1.26 \\
\hline Intercept & & -9.997 & -10.25 \\
\hline $\begin{array}{l}\text { Pseudo R2 } \\
\mathrm{N}\end{array}$ & & $\begin{array}{c}0.2626 \\
1,683\end{array}$ & \\
\hline
\end{tabular}

a. $\mathrm{p}<0.01 ;$ b. $\mathrm{p}<0.05 ;$ c. $\mathrm{p}<0.10$ 
Table 8: Panel B - Second Step, OLS estimation controlling for the predicted probabilities of adopting a particular incentive scheme (first stage)

\begin{tabular}{|l|cc|}
\hline & \multicolumn{2}{|c|}{ Carbon emissions } \\
\cline { 2 - 3 } & Coefficient & $t$-stat \\
\hline Only Non-monetary & -0.188 & -1.40 \\
Only Monetary & 0.139 & $\mathbf{1 . 8 8}^{\mathbf{c}}$ \\
Both Monetary and Non-monetary & 0.029 & 0.28 \\
Predicted Prob. of Providing Only Non-monetary & & \\
Predicted Prob. of Providing Only Monetary & -0.728 & -1.07 \\
Predicted Prob. of Providing Both Incentives & 0.729 & $\mathbf{1 . 7 3}^{\mathbf{c}}$ \\
& 0.438 & 0.94 \\
Sales & & \\
Sustainability Committee & 0.938 & $\mathbf{2 2 . 1 4}$ \\
Commercial Opportunities/Risks & 0.080 & 0.91 \\
\% monetary incentives for the country-year & 0.049 & 0.70 \\
\% non-monetary incentives for the country-year & -0.556 & -1.22 \\
Bonus plan & 0.335 & 0.57 \\
Join UN Global Compact by 2002 & -0.028 & -0.31 \\
Reduce carbon emissions & 0.013 & 0.09 \\
Reduce Transportation emissions & 0.301 & $\mathbf{3 . 1 9}$ \\
Reduce supply chain emissions & -0.151 & -1.63 \\
Sustainability Audit & -0.210 & $-\mathbf{2 . 4 6}$ \\
Intercept & 0.237 & $\mathbf{3 . 0 6}$ \\
\hline Country Fixed Effects & 15.51 \\
Industry Fixed Effects & 6.177 & \\
Year Fixed Effects & Yes \\
\hline Adj R-Squared & Yes & \\
N & Yes & \\
\hline
\end{tabular}

OLS regression using the natural logarithm of carbon emissions as the dependent variable, country fixed effects, industry fixed effects, year fixed effects and controlling for the predicted probabilities of adopting a particular incentive scheme. All standard errors are clustered at the firm level.

a. $\mathrm{p}<0.01$; b. $\mathrm{p}<0.05$; c. $\mathrm{p}<0.10$ 


\section{Appendix I - Investor CDP Survey Sample Compositions}

\begin{tabular}{|c|c|c|}
\hline Country & Office & $\begin{array}{l}\text { Sample size } \\
\text { (The largest companies, as measured by market capitalization) }\end{array}$ \\
\hline Asia (ex-Japan) & $\begin{array}{l}\text { Association for Sustainable and } \\
\text { Responsible Investment in Asia } \\
\text { (ASrIA) - Partner to CDP }\end{array}$ & $\begin{array}{l}170 \text { largest Asian companies (excluding Japan, China, India \& } \\
\text { Korea) - Hong Kong (75), Taiwan (25 companies), Malaysia (15), } \\
\text { Singapore (23), Indonesia (10 ), Thailand (10), Philippines (10), and } \\
\text { China (2 }\end{array}$ \\
\hline $\begin{array}{l}\text { Australia and } \\
\text { New Zealand }\end{array}$ & $\begin{array}{l}\text { Investor Group on Climate Change } \\
\text { (IGCC) - Partners to CDP }\end{array}$ & ASX 200 / NZX 50 \\
\hline $\begin{array}{l}\text { Belgium, } \\
\text { Netherlands, } \\
\text { Luxembourg }\end{array}$ & CDP Germany & Benelux 150 \\
\hline Brazil & $\begin{array}{l}\text { CDP Brazil / Latin America together } \\
\text { with the Brazilian Association of } \\
\text { Pension Funds (ABRAPP), Fábrica } \\
\text { Éthica Brasil and BANCO REAL - } \\
\text { Partners to CDP }\end{array}$ & $\begin{array}{l}80 \text { largest companies in Brazil listed on the BOVESPA São Paolo } \\
\text { Stock Exchange }\end{array}$ \\
\hline Canada & CDP North America & Canada 200 \\
\hline $\begin{array}{l}\text { Central \& } \\
\text { Eastern Europe } \\
\text { (CEE) }\end{array}$ & $\begin{array}{l}\text { Iparfejlesztési Közalapítvány (IFKA - } \\
\text { Public Foundation for the Progress of } \\
\text { the Industry) - Partner to CDP }\end{array}$ & $\begin{array}{l}\text { CEE } 100 \text { largest companies in CEE - Poland (56), Hungary (9), } \\
\text { Slovenia (8), Czech Republic (6), Slovakia (4), Lithuania (4), } \\
\text { Romania (3), Austria (2), Netherlands (2), (Serbia (1), Croatia (1), } \\
\text { UK (1), Estonia (2) and USA (1) }\end{array}$ \\
\hline China & Local Agent: SynTao & China 100 \\
\hline Europe & Europe & $\begin{array}{l}\text { FTSEurofirst } 300 \text { Eurozone: } 300 \text { largest companies in Europe - UK } \\
\text { (62), France (52), Germany (35), Switzerland (27), Spain (20), } \\
\text { Sweden (19), Italy (18), Netherlands (14), Belgium (10 ), Norway } \\
\text { (7), Austria (6), Denmark (6 ), Finland (6), Portugal (5), Ireland (4), } \\
\text { Luxembourg (4), Greece (2), Australia (1), Mexico (1) and the USA } \\
\text { (1) }\end{array}$ \\
\hline France & CDP France & SBF 250 \\
\hline $\begin{array}{l}\text { Germany and } \\
\text { Austria }\end{array}$ & CDP Germany & Germany and Austria 250 \\
\hline Global CDP & UK and USA offices & $\begin{array}{l}\text { Global 500: Top } 500 \text { companies within the FTSE Global Equity } \\
\text { Index Series }\end{array}$ \\
\hline India & Confederation of Indian Industry (CII & India 200 \\
\hline
\end{tabular}




\begin{tabular}{|c|c|c|}
\hline & $\begin{array}{l}\text { CESD), and WWF India - Partners to } \\
\text { CDP }\end{array}$ & \\
\hline Iberia 125 & $\begin{array}{l}\text { CDP Southern Europe together with } \\
\text { ECODES and BBVA - Partners to } \\
\text { CDP }\end{array}$ & $\begin{array}{l}\text { Spain 85: largest companies within IBEX } 35 \text { and FTSE Spain All } \\
\text { Cap Index and Portugal } 40\end{array}$ \\
\hline Ireland & CDP Ireland & Ireland 40 \\
\hline Italy & $\begin{array}{l}\text { CDPSouthern Europe, together with } \\
\text { Accenture, Banca Monte Paschi di } \\
\text { Sienna and the Kyoto Club - Partners } \\
\text { to CDP }\end{array}$ & Italy 100 \\
\hline Japan & CDP Japan & Japan 500 \\
\hline Latin America & $\begin{array}{l}\text { CDP Brazil / Latin America together } \\
\text { with the Brazilian Institute of Investor } \\
\text { Relations (IBRI) and Fábrica Éthica } \\
\text { Brasil - Partner to CDP }\end{array}$ & $\begin{array}{l}\text { Latin America 50: } 50 \text { largest companies in Latin America - Brazil } \\
\text { (16), Mexico (14 ), Chile (13), Peru (5) and Argentina (2) }\end{array}$ \\
\hline Korea & $\begin{array}{l}\text { Korean Sustainability Investing Forum } \\
\text { (KoSIF) and Eco-Frontier - Partners to } \\
\text { CDP }\end{array}$ & KRX 200: Korea Exchange 200 Index \\
\hline Nordic Region & $\begin{array}{l}\text { CDP Nordic, together with ATP and } \\
\text { KLP Asset Management - Partners to } \\
\text { CDP }\end{array}$ & $\begin{array}{l}\text { Nordic 260: } 260 \text { largest companies in Nordic region - Sweden (90), } \\
\text { Norway (65), Denmark (44), Finland (48), Bermuda (3), UK (3), } \\
\text { and Canada (2), Cyprus (1), Iceland (1), Belgium (1), Malta (1), } \\
\text { USA (1) }\end{array}$ \\
\hline Russia & CDP London & RTS Index 50: 50 largest companies in Russia \\
\hline South Africa & $\begin{array}{l}\text { National Business Initiative (NBI) - } \\
\text { Partner to CDP }\end{array}$ & FTSE/JSE 100 \\
\hline Switzerland & $\begin{array}{l}\text { CDP Germany, together with Ethos } \\
\text { and Pictet Asset Management - } \\
\text { Partners to CDP }\end{array}$ & $\begin{array}{l}\text { Switzerland 100: } 100 \text { of the largest companies (SPI Large \& Mid } \\
\text { Cap (SOCI)) }\end{array}$ \\
\hline Turkey & $\begin{array}{l}\text { Sabanci University Corporate } \\
\text { Governance Forum -Partners to CDP }\end{array}$ & ISE 100: 100 of the largest companies \\
\hline UK & CDP UK & FTSE 350 \\
\hline USA & CDP North America & S\&P 500 \\
\hline Electric Utilities & CDP UK and International Partners & 250 of the largest Electric Utilities companies globally \\
\hline Transport & CDP UK and International Partners & 100 of the largest Transport companies globally \\
\hline
\end{tabular}




\section{Appendix II - Investor CDP Survey Sample Answers}

The following 2009 sample answers to Q26.2 provide a glimpse into what firms mean by monetary incentives or non-monetary incentives when they answer the question.

\section{Monetary incentives:}

...At a lower management level relevant managers' performance targets are related to the climate change program objectives and personal bonuses are influenced by the progress in achieving the goals. A senior manager owns the GHG target...

...Allianz managers that are in charge of climate change products and services have their incentives related to monetary rewards. Allianz Group is furthermore considering the introduction of a monetary incentive scheme for individual Allianz operating entities and executives that are responsible for the reduction of GHG emissions in line with our Group Climate Strategy. Such a bonus related incentive is already in place at Allianz Germany for respective managers implementing carbon emission reduction measures...

...BG Group operates a cash-based Annual Incentive Scheme (AIS) for its employees. The performance of both the company and the individual combine to determine the value of the award paid under the AIS. The GHG reductions targets form part of the scorecard for the group (which covers all employees) against which performance is evaluated...

\section{Non-monetary incentives:}

...ConAgra Foods recognizes project teams for outstanding projects related to "Climate Change and Energy Efficiency” (as well as four other categories related to sustainability performance) through our internal Sustainable Development Awards program. Team members from the five project finalists in each 
category are invited to Omaha for an awards event and conference. Project teams recognized with a Sustainable Development Award are given \$5,000 to donate to an environmental nonprofit in their local community...

...Through the ISO14001 certification process, Air France - KLM is involving each employee in order to inform him about company's environmental policy and to stimulate him to participate actively into the Air France - KLM commitments, which includes climate change issues...

...Campbell has several employee recognition programs that can and have been used to provide incentives for management of GHG targets. The Company's most prestigious global recognition, the Campbell Extraordinary Performance Awards has a specific Sustainability Category and both of last year's winners in that category included projects with measurable impacts on GHG targets... 